\title{
How science makes environmental controversies worse
}

\author{
Daniel Sarewitz \\ Consortium for Science, Policy, and Outcomes, Arizona State University, P.O. Box 874401, Arizona, AZ 85287-4401, USA
}

\begin{abstract}
I use the example of the 2000 US Presidential election to show that political controversies with technical underpinnings are not resolved by technical means. Then, drawing from examples such as climate change, genetically modified foods, and nuclear waste disposal, I explore the idea that scientific inquiry is inherently and unavoidably subject to becoming politicized in environmental controversies. I discuss three reasons for this. First, science supplies contesting parties with their own bodies of relevant, legitimated facts about nature, chosen in part because they help make sense of, and are made sensible by, particular interests and normative frameworks. Second, competing disciplinary approaches to understanding the scientific bases of an environmental controversy may be causally tied to competing value-based political or ethical positions. The necessity of looking at nature through a variety of disciplinary lenses brings with it a variety of normative lenses, as well. Third, it follows from the foregoing that scientific uncertainty, which so often occupies a central place in environmental controversies, can be understood not as a lack of scientific understanding but as the lack of coherence among competing scientific understandings, amplified by the various political, cultural, and institutional contexts within which science is carried out.

In light of these observations, I briefly explore the problem of why some types of political controversies become "scientized" and others do not, and conclude that the value bases of disputes underlying environmental controversies must be fully articulated and adjudicated through political means before science can play an effective role in resolving environmental problems.
\end{abstract}

(c) 2004 Elsevier Ltd. All rights reserved.

Keywords: Values; Politics; Science policy; Environmental policy; Lomborg

\section{Introduction}

One may or may not find believable the claim by Bjorn Lomborg, author of The Skeptical Environmentalist, that, starting out as "an old left-wing Greenpeace member" gloom-and-doom environmentalist (Lomborg, 2001, p. xix) he gradually convinced himself, through the power of statistical analysis, that the environmental conditions upon which humanity depends for its well-being were not getting worse, but were actually getting better. Whether or not Lomborg did undergo a data-induced perceptual transformation, his underlying claim is a familiar and comfortable one. Our commitments to acting in the world must be based on a foundation of fact, and when a conflict arises between the two, then our commitments must accordingly change. Thomas Lovejoy, in a sharply critical review of Lomborg's book, nevertheless supports a similar view, where appropriate action is determined by scientific inquiry: "researchers identify a potential problem, scientific examination tests the various hypotheses, understanding of the problem often becomes more complex, researchers suggest remedial policies-and then the situation improves" (Lovejoy, 2002,

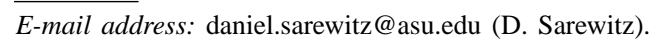

p. 12; emphasis in original). David Pimentel, another Lomborg critic, argues in the same vein: "As an agricultural scientist and ecologist, I wish I could share Lomborg's optimism, but my investigations and those of countless other scientists lead me to a more wary outlook" (Pimentel, 2002, p. 297).

So Lomborg and his critics share the old-fashioned idea that scientific facts build the appropriate foundation for knowing how to act in the world. How, then, are we to understand the radical divergence of the supposedly science-based views held by opposing sides in the controversy? If we accept the arguments of the critics, the divergence is simply a reflection of Lomborg's (perhaps willful) misunderstanding of the data. Yet, as Harrison (this issue) amply documents, Lomborg also has his supporters within the community of scientists. Are we instead witnessing a debate that exists because the science is incomplete, and thus allows for different interpretations? Stephen Schneider (2002, p. 1), another of Lomborg's critics, notes: "I readily confess a lingering frustration: uncertainties so infuse the issue of climate change that it is still impossible to rule out either mild or catastrophic outcomes, let alone provide confident probabilities for all the claims and counterclaims made about environmental problems." 
There is an obvious problem of causation here. If the science is insufficiently certain to dictate a shared commitment to a particular line of action, from where do these commitments spring? For Lovejoy, the process starts when "researchers identify a potential problem," but the recognition that something is a "problem" demands a pre-existing framework of values and interests within which problems can be recognized. And Pimentel's "wary outlook" (not to mention Lomborg's rosy one) presupposes some expectations of what the world ought to look like in the first place.

This paper thus confronts a well-known empirical problem. In areas as diverse as climate change, nuclear waste disposal, endangered species and biodiversity, forest management, air and water pollution, and agricultural biotechnology, the growth of considerable bodies of scientific knowledge, created especially to resolve political dispute and enable effective decision making, has often been accompanied instead by growing political controversy and gridlock. Science typically lies at the center of the debate, where those who advocate some line of action are likely to claim a scientific justification for their position, while those opposing the action will either invoke scientific uncertainty or competing scientific results to support their opposition. ${ }^{1}$

A significant body of literature both documents and seeks to understand this dynamic (see, e.g., the admirable synthesis by Jasanoff and Wynne, 1998). This literature is characterized, for example, by the understanding that scientific facts cannot overcome, and may reinforce, value disputes and competing interests (e.g., Nelkin, 1975; Nelkin, 1979; Collingridge and Reeve, 1986), that scientific knowledge is not independent of political context but is co-produced by scientists and the society within which they are embedded (e.g., Jasanoff, 1996a), that different stakeholders in environmental problems possess different bodies of contextually validated knowledge(e.g., Wynne, 1989), and that the boundaries between science and policy or politics are constantly being renegotiated as part of the political process (e.g., Jasanoff, 1987; Jasanoff, 1990).

This work adds up to a deeply textured portrayal of the troubled relationship between science and decision making in the realm of the environment. Yet, as the Lomborg controversy highlights to a degree that is almost painful, high-profile public discourse surrounding environmental disputes remains stubbornly innocent of this past 20 or more years of constructivist scholarship. The notion that science is a source of facts and theories about reality that can and should settle disputes and guide political action remains a

\footnotetext{
1 This dynamic does not discriminate on the basis of ideology: in the case of the Yucca Mountain nuclear waste repository, the claim that the science is sufficient to justify action (i.e., construction of the site) has most strongly been invoked by those with a politically conservative bent; in the case of climate change, it is political liberals who have been more likely to claim that the science is sufficient to justify a particular line of action (mandated reductions of greenhouse gas emissions).
}

core operating principle of partisans on both sides of the Lomborg case and other environmental controversies. ${ }^{2}$

Much, perhaps most, of the recent literature grounds its critique in the difficulties associated with the first component of this pervasive and strongly held notion - that science is a source of verifiable facts and theories about reality. In this paper, I treat this realist notion not as a contestable idea but as an initial condition of the policy context-a starting point for further analysis. My goal is to offer an interpretation of the current, lamentable state of affairs whose acceptance by political actors does not require an abandonment of fundamental cosmologies. Thus, I look for explanation not in the social construction of science, but precisely in "the fact that scientists do exactly what they claim to do," (Hull, 1988, p. 31) and argue that the fulfillment of this promise is what gets us deeper into the hot water-science does its job all too well. The argument, in brief, is this: nature itself-the reality out there-is sufficiently rich and complex to support a science enterprise of enormous methodological, disciplinary, and institutional diversity. I will argue that science, in doing its job well, presents this richness, through a proliferation of facts assembled via a variety of disciplinary lenses, in ways that can legitimately support, and are causally indistinguishable from, a range of competing, value-based political positions. I then show that, from this perspective, scientific uncertainty, which so often occupies a central place in environmental controversies, can be understood not as a lack of scientific understanding but as the lack of coherence among competing scientific understandings. These considerations lead me finally to consider the question of why environmental controversies tend to become highly "scientized," and to speculate about what might happen if we could "de-scientize" them.

But first, as a sort of control case, it might be helpful to visit a major political controversy that was not resolved through resort to scientific research: the 2000 US Presidential election.

\section{Determining an integer}

The front page of the 6 May 2000 Washington Post reported that political scientists were using mathematical models to predict the winner of the forthcoming US Presidential election between Democratic candidate Al Gore and Republican George W. Bush (Kaiser, 2000). The models, which integrated such factors as the state of the economy and public opinion data, indicated that Gore would handily win the election. But by the time the polls in most states had closed, it was apparent that victory in this remarkably close election would depend on the outcome of the vote in the populous and tightly contested state of Florida, with its

\footnotetext{
${ }^{2}$ Perhaps paradoxically, the notion persists despite carefully argued claims about the delegitimation of the authority of science in society (e.g., Ezrahi, 1990).
} 
25 electoral votes. At about 8:00 p.m. on election night, the major television networks famously declared Gore the winner on the basis of data from Florida exit polls. But as the actual Florida returns came in, it soon became clear that the race was too close to call, and the networks rescinded their initial prediction of a Gore victory. Early the next morning, the networks named Bush the victor, but they soon learned that the closeness of the vote would trigger an automatic recount, so again they had to reverse themselves. A day later, with all precincts reporting, the initial vote count for Florida indicated a difference between Gore and Bush of about 1800 votes out of almost six million cast-a margin of less than three hundredths of a percentage point.

With so much at stake, the vote count was of course furiously contested, with claims of irregularities, miscounts, misvotes, machine failure, and even voter intimidation, and demands for recounts. Yet the basic contention focused on the determination of a single, apparently simply fact: how many votes did each candidate receive?

This is a remarkably straightforward-seeming problem, with an apparently clear path to resolution: count all votes and determine the winner. Yet, in the end, the winner of the Florida vote was not determined by an assertion of fact, it was determined through the resolution of a legal battle between lawyers representing the interests of each candidate, and decided by the Supreme Court of the United States (2000). The decision overturned an earlier Florida Supreme Court ruling that would have allowed additional recounts. In so doing, it accepted a vote count that had been previously certified by the state of Florida, which showed Bush to be the winner (now by 537 votes) despite ongoing uncertainties about the actual tally. In other words, the Court asserted that the final answer to the question "Who got more votes in Florida?" was appropriately determined by legal and political processes.

\subsection{A thought experiment}

Would not it have made more sense to simply get a definitive count of the votes to objectively determine the winner? Imagine that the contesting parties had agreed that the problem was a technical one, not a legal or political one, and that they had turned the vote counting over to a team of disinterested experts whose job would be to determine the correct result. On its face, it is hard to imagine a problem more suited to a strictly technical approach. The system under consideration-an election-is in principle a closed one, with a finite number of system components (voters; voting machines; vote counting procedures) obeying simple decision rules (each voter votes once for one candidate based on personal preference; all votes for each candidate are added up) within clearly defined spatial (the state of Florida) and temporal (the time period during which the polls were open) boundaries. The correct answer is known to be an integer, and it is derived through the simplest possible arithmetic process.
Of course the political debate over the vote count revealed system complexities. Overvotes (ballots that were not counted because they appeared to contain votes for more than one candidate) and undervotes (ballots that were not counted because they appeared not to indicate a vote for any candidate) totaled more than 175,000 -more than three hundred times the final, certified 537 vote differential between Bush and Gore (Merzer, 2001). Many of these ballots seemed to indicate the intent of the voter (for example, in cases where voters had not pushed the vote-punch machine hard enough to fully separate the chad from the card; or where voters had both punched and written in a vote for the same candidate). Confusing ballot graphics may have led some people to vote for the wrong candidate. More generally, the reliability of various voting technologies was called into question.

So the team of experts tasked with coming up with the final vote tally might need to be drawn from several disciplines. For example, there would certainly need to be a statistics group to develop models of reliability for different types of voting machines. Statisticians would also need to develop rigorous error analyses that would characterize the probabilities that a given tally actually determined the real victor. A technology evaluation group would need to assess the sources of failure for different types of machines, while a cognitive neuroscience group might look at visual perception problems to try to understand the extent to which ballot design could contribute to wrong votes. Fundamental research could address such questions as chad behavior under different states of compressive stress (material science), the relation between the physical strength of the voter and chad behavior (physiology), the variable behavior of vote-punch machines (mechanical engineering), and the causes of overvotes (psychology).

The first result of these analyses would likely be reports with technical-sounding titles such as "Florida's Residual Votes, Voting Technology, and the 2000 Election," or "Elections: Statistical Analysis of Factors that Affected Uncounted Votes in the 2000 Presidential Election," or "The Butterfly Did It: The Aberrant Vote for Buchanan in Palm Beach County, Florida." 3 Once the experts began to make their results known, other experts would need to review them, and disagreements-over methodology, data, and conclusions - would undoubtedly emerge. Studies from different disciplines would need to be integrated, and even then the final calculations would have to be governed by rules about what constitutes a valid vote. Normative questions (such as whether the vote count should capture the intent of all voters, or simply record "actual" votes, which would in turn raise questions about what "actual" meant) would thus govern both the design of studies and the interpretation of results, and we could expect that the political backgrounds and affiliations of the experts would be exhaustively

\footnotetext{
${ }^{3}$ In fact, these are the titles of published papers: Leib and Dittmer (2002), US General Accounting Office (2001), and Wand et al. (2001).
} 
scrutinized to try to sniff out potential conflicts of interest. To make matters yet more complex, ideological affinity would probably influence what type of science one was willing to accept, because different approaches to counting would have different implications for the election results. In this light, because so many of the uncounted overvotes and undervotes were from precincts with Democratic majorities, ${ }^{4}$ Bowker and Star (2001, p. 422) recognized "a party political divide [that] aligned the purity of numbers with the Republican right and a faith in statistics with the Liberal left."

Can we really imagine that such a technical process would have led to a swift determination of the "real winner" in a timely fashion, and in a manner that preserved the legitimacy of the electoral system and the eventual winner? Would the experts have been able to arrive at a number-a simple integer-that everyone could agree on as the "right" answer, and that all contesting interests would have accepted? Indeed, the Miami Herald sponsored an unofficial recount of over- and undervotes which showed that either Gore or Bush could have been the winner depending on criteria used to judge the validity of ballots.

In contrast, it should be remembered that the politi$\mathrm{cal} /$ judicial process that actually was followed did accomplish these goals, conferring a final decision in 36 days, and yielding a new president who was broadly accepted despite the fact that more than half of the nation's voters had opposed him, and in the absence of any agreement of what the final vote tally "actually" was.

This story and thought experiment are meant to highlight four points.

1. Even apparently simple systems can display unprecedented, surprising behavior. Fifty-two previous presidential elections were not enough to reveal all possible system behaviors and permit accurate prediction of future outcomes.

2. The same uncertainties that were revealed in the Florida election no doubt exist in all elections. They became significant because the election was so close (both sides could reasonably visualize themselves as potential winners-or losers), and because the stakes were enormously high - the presidency would be determined by its outcome.

3. The dispute was not resolved by addressing the technical aspects of the vote count, but by subjecting the vote count process to political and judicial mediation procedures that were legitimated by their capacity not to arrive at "truth" but to transparently negotiate among competing players. But because this system was broadly accepted as legitimate - that is, people understood and agreed on the rules-its results were also broadly accepted. More-

\footnotetext{
${ }^{4}$ Studies by various social scientists (e.g., Wand et al., 2001 and Heron and Sekhon, 2003) have sought to show that the intent on many overvoted ballots could be inferred, and have concluded that high prevalence of uncounted overvotes in strongly Democratic counties worked strongly in favor of Bush.
}

over, the result is not permanent-it will be revisited in the next election.

4. A purely technical approach, aimed at overcoming uncertainty about the vote count, and subject both to the strictures of scientific method and the close attention of the public, could not have achieved resolution as quickly, as decisively, or as legitimately, as the political/legal approach.

\section{Excess of objectivity}

I want to explore the possibility that environmental controversies typically bear a much greater likeness to the 2000 Florida election controversy than might at first seem apparent. To do so I begin by considering why facts ${ }^{5}$ often fail to behave in the manner that both Lomborg and his critics claim they should.

In July 2003, two conservative think-tanks, the Hoover Institution on War, Revolution and Peace at Stanford University, and the George C. Marshall Institute in Washington, DC, published a book entitled Politicizing Science: The Alchemy of Policymaking (Gough, 2003). The book visited a number of examples, from a right-wing perspective, of how science had been manipulated, distorted, or suppressed, mostly in support of liberal causes, mostly related to the environment. The underlying theme of the book was that science could guide politics only when it was free from ideology. "The more that political considerations dominate scientific considerations, the greater the potential for policy driven by ideology and less based on strong scientific underpinnings" (2003, p. 3). The point, of course, is that "policy driven by ideology" is supposed to be undesirable.

The next month, Congressman Henry Waxman, a liberal Democrat, released a report entitled "Politics and Science in the Bush Administration" (United States House of Representatives, 2003), which pointed to numerous examples of how the Administration "manipulated the scientific process and distorted or suppressed scientific findings" to yield results that favored the interests of its supporters.

While neither of these publications were works of scholarly research, and both made some points that seem reasonable and others that are less so, the more interesting observation is that, in coming from strongly contrasting ideological positions, they (along with the combatants in the Lomborg controversy) shared a view of science as a disinterested force that could guide political decision making by providing appropriate facts-so long as it was kept separate from politics. Yet the simultaneous appearance of these two products amusingly highlights what neither side was willing or able to contemplate: if everyone politicizes the science, maybe there is something about science that lends itself to being politicized?

\footnotetext{
${ }^{5}$ I am content to use a conventional definition of "fact," e.g., a statement about the world whose truth or falseness can be tested.
} 
Consider climate change, which may variously be understood as a "problem" of climate impacts, weather impacts, biodiversity, land use, energy production and consumption, agricultural productivity, public health, economic development patterns, material wealth, demographic patterns, etc. Each of these ways of looking at the problem of climate change involves a variety of interests and values, and each may call on a body of relevant knowledge to help understand and respond to the problem. Not only may the interests, values, and knowledge relevant to one way of understanding the problem be, in small part or large, different from those associated with another way, but they may also be contradictory. Conversely, those holding different value perspectives may see in the huge and diverse body of scientific information relevant to climate change different facts, theories, and hypothesis relevant to and consistent with their own normative frameworks. This condition may be termed an "excess of objectivity," because the obstacle to achieving any type of shared scientific understanding of what climate change (or any other complex environmental problem) "means," and thus what it may imply for human action, is not a lack of scientific knowledge so much as the contrary-a huge body of knowledge whose components can be legitimately assembled and interpreted in different ways to yield competing views of the "problem" and of how society should respond. Put simply, for a given value-based position in an environmental controversy, it is often possible to compile a supporting set of scientifically legitimated facts.

A familiar illustration is the documentation of global warming. While the observation of a global warming signal over the past 20 years is well accepted, discrepancies between surface temperature measurements and lower-to-middle troposphere temperature data from satellites and radiosondes continue to offer scientifically credible facts for global warming "contrarians." A National Academy of Sciences report (NRC, 2000) failed to resolve this conflict, concluding that, on the one hand, "the warming trend in global-mean surface temperature observations during the past 20 years is undoubtedly real" and also that "the troposphere actually may have warmed much less rapidly than the surface from 1979 into the late 1990s" (NRC, 2000, p. 2) ${ }^{6}$

Yet resolving the discrepancy to everyone's satisfaction would not really solve anything. After all, the fact of global warming is not itself inherently problematic; what worries us is the possibility that warming will cause a variety of undesirable outcomes. When global warming is considered in terms of its specific potential social consequences, however, the availability of competing facts and scientific perspectives quickly spirals out of control. Consider the following

\footnotetext{
6 The first goal listed in the Strategic Plan for the US Climate Change Science Program (Climate Change Science Program, 2003) is to reconcile surface and lower atmosphere temperature records, whose inconsistencies "reduce confidence in understanding of how and why climate has changed."
}

chain of logic: human greenhouse gas emissions are causing global warming; global warming will lead to increased frequency and severity of extreme weather events; reducing greenhouse emissions can thus help reduce the impacts of extreme weather events. Each link in this chain is saturated with the potential for competing, fact-based perspectives. For example, climate models and knowledge of atmospheric dynamics suggest that increased warming may contribute to a rising incidence and magnitude of extreme weather events (Houghton et al., 2001, p. 575); but observations of weather patterns over the past century do not show clear evidence of such increases, while model results are still ambiguous, and "data continue to be lacking to make conclusive cases" (Houghton et al., 2001, p. 774). While economists can show how tradable permit schemes combined with mandated emissions targets can reduce greenhouse gas emissions (Chichilnisky and Heal, 1995), they cannot agree on plausible future rates of emissions increase (The Economist Print Edition, 2003). Furthermore, perspectives on the history and economics of innovation suggest that decarbonization is likely to depend primarily on technology evolution and diffusion, not policies governing consumption (Ausubel, 1991; Nakicenovic, 1996). Social science research on natural hazards suggests that socioeconomic factors (such as land use patterns, population density, and economic growth), rather than changing magnitude or frequency of hazards, are responsible for increasing societal losses from extreme events (Pielke et al., 2003; Changnon et al., 2001). And in any case, climate scientists disagree about the extent to which greenhouse gases are responsible for warming trends, given that other phenomena, such as land use patterns, may also strongly influence global climate (e.g., Marland et al., 2003). Finally, climate models that as yet have no capacity to accurately predict regional variability in extreme events are thus even further from providing useful information about how greenhouse gas emissions reductions might influence future incidence and magnitude of extreme events. Each level of analysis is not only associated with its own competing bodies of contestable knowledge and facts, but is also dependent on how one views the other levels of analysis. Facts can be assembled to support entirely different interpretations of what is going on, and entirely different courses of action for how to address what is going on.

As Michael (1995, p. 473) explained, in the context not of global warming but ecosystem management: "More information provides an ever-larger pool out of which interested parties can fish differing positions on the history of what has led to current circumstances, on what is now happening, on what needs to be done, and on what the consequences will be. And more information often stimulates the creation of more options, resulting in the creation of still more information" (also see Herrick and Jamieson, 1995; Herrick and Sarewitz, 2000; Sarewitz, 2000).

As an explanation for the complexity of science in the political decision making process, the "excess of objectivity" argument views science as extracting from 
nature innumerable facts from which different pictures of reality can be assembled, depending in part on the social, institutional, or political context within which those doing the assembling are operating. This is more than a matter of selective use of facts to support a pre-existing position. ${ }^{7}$ The point is that, when cause-and-effect relations are not simple or well-established, all uses of facts are selective. Since there is no way to "add up" all the facts relevant to a complex problem like global change to yield a "complete" picture of "the problem," choices must be made. Particular sets of facts may stand out as particularly compelling, coherent, and useful in the context of one set of values and interests, yet in another appear irrelevant to the point of triviality. ${ }^{8}$

\section{Value in discipline}

While this argument may help make clear why "more science" often stokes, rather than quenches, environmental controversies, I believe it does not go far enough. It seems to me that there is likely to be a causal connection between the ways that we have organized scientific inquiry into nature, and the ways we organize human action (and thus political decision making) related to the environment.

For example, consider the controversy over the Acoustic Thermometry of Ocean Climate (ATOC) experiment. The history of this controversy is discussed in detail in Oreskes (2004). In brief, oceanographers at the Scripps Institution of Oceanography designed a clever experiment to measure changes in the global average temperature by monitoring how the velocity of sound waves traveling over long distances in the ocean were changing over time. ATOC was promoted as the experiment that could finally settle the question of whether, and how fast, global warming was actually occurring. However, an alliance of environmentalists and biologists opposed the experiment because of concerns about its effects on whales and other marine mammals. While designers of the experiment sought to assure the opponents that the experiment would not harm marine mammals, they lacked both the scientific legitimacy, and the institutional disinterest, to make a convincing case. A National Research

\footnotetext{
7 My point is not to excuse conscious manipulation of facts, or to deny that some research simply is not of a very good quality. But the elimination of these two problems would have little if any effect on the phenomenon I am describing. The problem is not "good" versus "bad" but "ours" versus "theirs" (e.g., see Herrick and Jamieson, 2001 on "junk science").

${ }^{8}$ A conspicuous example of such of non-intersecting worldviews is the almost complete lack of cross fertilization between scientists who generate model-based scenarios of future climate behavior, and researchers who study hazards and their reduction. As one indication of this divide, these communities use the word "mitigation" in opposite senses. To the climate modeling community, mitigation means prevention of climate change through greenhouse gas emissions reduction (mitigation of cause). To the hazards community, mitigation means protection from climate impacts through, e.g., better land use planning or infrastructure (mitigation of effects).
}

Council (NRC) study was commissioned to resolve the dispute, and while it was unable to confirm the potential for ATOC to harm marine mammals, neither could it entirely discount the possibility. Oceanographers working on the experiment interpreted the report as a green light for ATOC, while biologists saw it as a vindication of their opposition.

Oceanographers were primarily concerned about conducting an oceanographic experiment that would document global warming. Biologists were primarily concerned about the effects of acoustic transmissions on the well-being of marine mammals already under assault from human activities. These positions are not reconcilable because there is nothing to reconcile- they recognize and respond to different problems. They also point to a direct connection between scientific perspectives and values. Oceanographers chose to interpret the uncertainty associated with the National Research Council study as an endorsement of the safety of ATOC. Biologists interpreted the same study as an affirmation of potential harm. Scientific orientation helped to determine one's assessment of the level risk posed by ATOC, ${ }^{9}$ one's willingness to face that risk, and one's view about the potential benefits of ATOC (Oreskes, 2004). There is a notable incoherence in this debate-an incommensurability of contesting fact-value positions ("contradictory certainties," to use Schwarz and Thompson's (1990, p. 60) memorable term). The benefits of performing ATOC, as understood and articulated by physical oceanographers, had no bearing on the well-being of marine mammals, as understood by biologists. To put it bluntly, but perhaps not too simplistically, oceanographers' values were represented by the conduct and outputs of oceanography; biologists' values were not.

Could scientific orientation be related to the values that one holds? Science divides up the environment partly by disciplinary orientations that are characterized by particular methods, hypotheses, standards of proof, subjects of interest, etc. My point is certainly not that disciplines are associated with monolithic worldviews and value systems. But, while some see a grand unification of all knowledge as an inevitable product of scientific advance (Wilson, 1998), thus far the growth of disciplinary scientific methods and bodies of knowledge results in an increasing disunity that translates into a multitude of different yet equally legitimate scientific lenses for understanding and interpreting nature (e.g., Dupré, 1993; Rosenberg, 1994; Cartwright, 1999; Kitcher, 2001, chapter 6). Similarly, individual humans can have only the most partial of understandings of the world in which they reside, and it is in the context of these always-incomplete understandings that they make their decisions and judgments (e.g., Simon, 1997 and Simon, 1983). Without saying anything about direction of causation, it seems entirely plausible to suggest that the formal intellectual framework used by a scientist to understand some slice of the world may be

\footnotetext{
9 Similarly, Barke and Jenkins-Smith (1993) showed that scientists' perception of risk related to nuclear waste disposal was related to disciplinary orientation.
} 
causally related to that scientist's normative framework for interpreting and acting in the world.

The ongoing debate over genetically modified organisms (GMOs) in agriculture helps to illustrate the idea. There are many ways to "understand" GMOs: in terms of their connection to food production, human health, economic development, ecosystem dynamics, biotechnology innovation processes, plant genetic diversity, even culinary arts. Each of these perspectives is associated in part with separate disciplinary perspectives. What might such diverse perspectives mean for how one views the "value" or "risks" of GMOs? Environmental benefits typically attributed to GMOs include: better resistance to environmental stresses; more agricultural productivity; fewer agrochemical inputs such as pesticides; and design of crops that can actually remediate polluted soils and aquifers. Environmental risks typically attributed to GMOs include: uncontrolled introgression of genes into other varieties or species; harmful mutations of inserted genes; competition and breeding with wild species; negative effects of insecticidal GMOs on beneficial non-target organisms such as birds and pollinating insects; and growing resistance of insects to insecticidal GMOs (Wolfenbarger and Phifer, 2000; Food and Agriculture Organization, 2003a,b). One obvious attribute of these two lists is that the putative benefits derive from straightforward cause-and-effect relations that reflect the intent of scientists working on GMOs, whereas the putative risks arise from more complex interactions that are largely unintended. It thus seems reasonable to expect that scientists from disciplines involved in design and application of GMOs, such as plant geneticists and molecular biologists, would be potentially more inclined to view GMOs in terms of their planned benefits, and ecologists or population biologists would be more sensitized to the possibility of unplanned risks at a systemic level.

These sorts of relations become palpable in trying to unravel the vicious debate sparked by the publication of a paper in Nature by Ignacio Chapela, a microbial ecologist, and his graduate student, David Quist, documenting the occurrence of transgenic corn in Mexico, and the introgression of the insecticidal $(\mathrm{Bt})$ transgenes into native maize varieties (Quist and Chapela, 2001). The original article, which went through Nature's standard peer review process, was attacked vociferously by numerous scientists, including former Berkeley colleagues of Quist and Chapela. Both the methods and the conclusions of the original paper were strongly criticized. One scientist called the paper "a testimony to technical incompetence," another termed it "so outlandish as to be pathetic," and a third dismissed it as "trash and indefensible" (Lepkowski, 2002a). These and other critics initially insisted that the issue was simply one of the quality of the science, but in reality the dispute was inextricably intertwined in the larger controversy over biotechnology. If the original results were correct it meant that GM corn had made its way into Mexico despite the fact that it was banned by the Mexican government, and, more damningly, that genes from the GM corn had moved into native Mexican varieties that are the original source of the world's genetic diversity for corn. If these conclusions turned out to be true, it could damage the prospects of the agricultural biotechnology industry, because it would indicate that the ecological and genetic impacts of GM corn were not predictable and could not be controlled.

An underlying theme of the debate was that Quist and Chapela's attackers were in the pocket of the biotechnology industry, or, from the opposite perspective, that Quist, Chapela, and their allies were shills for the anti-biotechnology lobby. Environmental and industry groups mobilized their constituencies on behalf of the scientists who best represented their interests. Scientists themselves traded accusations about the political motives and economic interests of those whose science they were attacking (Lepkowski, 2002a; Nature, 2002). If nothing else, the high stakes of the debate ensured that it would attract much more attention than a disagreement that was merely "scientific." As Nature editor Maxim Clarke observed: "scientists with strong interests scrutinize published papers more intently than they would otherwise do ... because they are very motivated to find any flaws which can be used to undermine or support the conclusions of the paper" (Lepkowski, 2002b).

Yet on another level that was never discussed, the disciplinary structure and disunity of science itself was at the roots of the controversy. The two sides of the debate represented two contrasting scientific views of nature-one concerned about complexity, interconnectedness, and lack of predictability, the other concerned with controlling the attributes of specific organisms for human benefit. In disciplinary terms, these competing views map onto two distinctive intellectual schools in life science-ecology and molecular genetics (e.g., see Holling, 1998).

Thus, it is not surprising that Quist and Chapela's strongest scientific critics were those whose own research focused on the genetic engineering of individual plant varieties, while their scientific supporters focused on ecosystem behavior (as did Quist and Chapela). Those representing the molecular genetics perspective aimed their critique at flaws in Quist and Chapela's techniques and the ambiguity of their results (Metz and Fütterer, 2002; Kaplinsky et al., 2002). Wayne Parrott of the University of Georgia, one of their most aggressive attackers, said:

"[W]hen we do our work, we run a PCR [polymerase chain reaction] first. Then we take our positive samples and do a more reliable test on them. Chapela used it in its entirety. He could have taken his positive samples and followed them up with something more definitive, such as spraying the things with a herbicide. Or he could have looked for a protein. There are many things he could have done that would have taken maybe a couple more weeks. No one would have questioned it. The thing is that he tried to get into a top journal by using a preliminary test. Then he makes all sorts of claims based on this. He used the 
wrong enzyme, he used the wrong extraction procedure, everything he did was wrong. And it's not worth the paper it's written on" (Lepkowski, 2002a).

But Allison Snow, a researcher at Ohio State University who studies gene flow in the environment, had a more generous view, despite acknowledging the methodological flaws:

"I don't think the science in the second half of their paper was very good. They said there were multiple insertions of transgenes, where they were going in the genome wasn't predictable, and that therefore that there was something scary about transgenes. But the first half of the paper, while you could always have asked them to do a better job, I thought was well supported. And anyway, a lot of people already believe that transgression has already happened and the Mexican government has confirmed it and talked about it in several news releases. What was interesting was Chapela's positive control with the grain from the local store. That had been shipped in from the United States as animal feed and was definitely transgenic. It was not for human consumption but people are planting it. So there are all those different parts to this puzzle" (Lepkowski, 2002a).

Parrott, whose analytical frame of reference is the gene, assessed Quist and Chapela's work strictly in terms of its adherence to the standards necessary for genetic engineering. Failing to pass muster from that perspective, he deemed the work worthless. Snow, whose focus is on the ecosystem scale, could acknowledge these flaws but still recognize that parts of the research had important implications for ecosystem behavior, and as well that the research reflected such scientific virtues as replicability of results and the clever identification of a control case.

The implications of these competing perspectives are readily apparent in the ways that Parrott and Snow describe their own work. Parrott's website says: "Our laboratory conducts research on crop genetic engineering, although its members also dabble in molecular markers. The bulk of the work deals with the development of protocols for ... genetic transformation of soybean, peanut, alfalfa, and maize" (Parrot Lab, 2003). In contrast, Snow says of her research: "I study microevolutionary processes in plant populations, with an emphasis on breeding systems, pollination ecology, and conservation biology ... Most recently, my research focuses on the applied question of how gene flow from cultivated species affects the evolutionary ecology of weedy relatives" (Snow, 2003). Parrott's concerns end with the "genetic transformation" of specific crops, while this transformation is the starting point for Snow's work.

In this context, there is nothing inherently implausible in the claims of scientists on both sides that their positions were scientific, not political or economic. Two of Quist and Chapela's critics, accused in a letter to Nature of having conflicts of interest because their research was partly funded by the biotechnology industry (Nature, 2002, p. 898) de- fended themselves in the following manner: "We are not unlike many scientists in that we have shared research and funding with industry at some point. In stating that we have 'compromised positions,' [our critics] wrongly imply that private-sector funding strips us of integrity and legitimacy in the arena of scientific discourse." One may accept this argument and still see a connection between the type of science being conducted, a worldview compatible with that science, and the interests of those who might find the science compelling and valuable. ${ }^{10}$

This alignment of disciplinary perspective and worldly interests is critically important in understanding environmental controversies, because it shows that stripping out conflicts of interest and ideological commitments to look at "what the science is really telling us" can be a meaningless exercise. Even the most apparently apolitical, disinterested scientist may, by virtue of disciplinary orientation, view the world in a way that is more amenable to some value systems than others. That is, disciplinary perspective itself can be viewed as a sort of conflict of interest that can never be evaded. In cases such as the Mexican corn controversy, it might be most accurate to look at the scientific debate not as tainted by values and interests, but as an explicit—if arcane-negotiation of the conflict between competing values and interests embodied by competing disciplines.

From a similar perspective, the economist Richard Norgaard (2002) assessed Lomborg's The Skeptical Environmentalist. Norgaard notes that economists have been generally sympathetic with Lomborg's optimistic evaluation of the state of the world's environment, while ecologists and other environmental scientists have been largely outraged. ${ }^{11}$ The reason, he suggests, is that "the thinking of economists requires the existence of scarcity," (2002, p. 288) and the history of industrial economies is one of overcoming scarcity through innovation. Progress through innovation and economic growth is a first principle underlying conventional economic dogma, and this principle dictates that current scarcity of environmental assets will be overcome in a similar manner. One presumes, although Norgaard is not explicit about this, that he sees environmental scientists as inherently less inclined toward an optimistic view of the future, perhaps because their disciplines do not include the faith in the inevitability of progress that he attributes to economics.

To summarize thus far: central to the idea that science can help resolve environmental controversies is the expectation that science can help us understand current conditions under which our decisions are being made, and the potential future consequences of those decisions. This expectation must confront the proliferation of available facts that can be

\footnotetext{
10 The point applies equally to Chapela, a long-time opponent of GM crops.

${ }^{11}$ For this reason, he also speculates-correctly, it turns out (Harrison, 2004) - that some or most of the peer reviewers of Lomborg's book mus have been economists.
} 
used to build competing pictures of current and future conditions, and the embeddedness of such facts in disciplinary perspectives that carry with them normative implications. These problems are in part a reflection of the diversity of human values and interests, but they also reflect the richness of nature, and the consequent incapacity of science (at least in this stage of its evolution) to develop a coherent, unified picture of "the environment" that all can agree on. This lack of coherence goes by the name of "uncertainty."

\section{Origins of uncertainty}

Reduction of uncertainty is a central, perhaps the central, goal of scientific research carried out in the context of environmental controversies ranging from climate change to ecosystem restoration, as variously articulated in innumerable policy documents, research reports, and scientific articles. The standard model, of course, is that if uncertainty surrounding the relevant scientific facts can be reduced, then the correct course of action will become more apparent. Uncertainty is thus portrayed as the cause of inaction. But the notion of a clearly demarcated body of relevant fact is highly problematic. And, as the 2000 election story shows, uncertainty about facts need not be an impediment to political resolution of heated controversy. The standard model will hold up. To begin to develop a more satisfactory alternative, I examine how estimates of uncertainty have changed in the arenas of earthquake prediction, nuclear waste disposal, and climate change. Based on these examples, I present the idea that uncertainty in environmental controversies is a manifestation of scientific disunity (excess of objectivity; disciplinary diversity) and political conflict.

\subsection{The Parkfield prediction}

In 1985, seismologists from the US Geological Survey estimated with $95 \%$ probability that a mid-size earthquake along the Parkfield segment of the San Andreas fault would occur by the year 1993. The $95 \%$ certainty level assigned to the event was derived from a statistical analysis of the recurrence interval of past earthquakes along the Parkfield segment (Bakun and Lindh, 1985) and it was endorsed by the scientific judgment of the seismological community as a whole, as expressed by expert oversight bodies at the state and national level (Nigg, 2000).

The earthquake, however, did not take place, and by the end of 2003 had still not occurred. One possible explanation is that reality is occupying the tail of the probability curve-that is, the $95 \%$ probability was "correct," and the non-occurrence of the earthquake was indeed a highly unlikely event reflecting aberrant behavior of the fault system (analogous, perhaps, to the uniquely rare confluence of events in the 2000 Florida election). If this were true, we would expect, for example, that if similar predictions were made for nineteen other, similar fault segments, earthquakes would occur in all cases. But the state of seismological knowledge has only rarely allowed scientists to issue earthquake predictions with confidence, and even more rarely have those predictions been borne out (Nigg, 2000). Indeed, subsequent analysis has shown that the Parkfield prediction was based on insufficient analysis of available data and incomplete understanding of the fault's behavior (Kagan, 1997; Roeloffs and Langbein, 1994). From this perspective, the uncertainty estimate needs to be recognized as a statement not about the actual behavior of a natural phenomenon, but about the state of scientific understanding of that phenomenon at a particular time, and the state of confidence that scientists had in that state of understanding at that time.

Uncertainty estimates, that is, are in part a measure of the psychological state of those making the estimates, which is in turn influenced by political context within which the science is carried out. In the case of the Parkfield prediction, an important aspect of the story was that the fault segment ran through a sparsely populated agricultural region of California. Thus, the political and economic stakes of a false prediction (or, for that matter, an accurate one) were low. If seismologists had arrived at similar probabilities for an earthquake in San Francisco, the consequences of both the prediction itself, and the predicted event, would have been considerably greater. Under such circumstances, scientific and political scrutiny of the prediction would have greatly intensified, the pressure on the scientists to be "right" would have been intense, and the population of scientists and perhaps of disciplines involved in the prediction process would have expanded. It is difficult to imagine that such conditions would not have influenced the certainty levels expressed by scientists, or undercut the unanimity of opinion surrounding particular statements of certainty. If the stakes had been higher, certainty would have been lower.

\subsection{Water flowing underground}

One key attribute that determines the performance of any nuclear waste site is its hydrological system. If water flows through a site, it may accelerate degradation of waste containment vessels that could in turn lead to mobilization of radionuclides and contamination of water supplies and the environment adjacent to the site. Because radioactive waste decays over periods of tens of thousands of years, assessing the behavior of a potential site involves efforts to understand how the hydrological system might evolve over long time frames. $^{12}$

Since the early 1980s, hydrologists have been estimating percolation flux, or the rate at which a volume of water flows through a unit area of rock, at the proposed US high level nuclear waste site at Yucca Mountain, Nevada. Initial estimates, made in the early 1980 s based on field studies, indicated a flux of between 4 and $10 \mathrm{~mm}$ per year, but further research reduced these estimates to between 0.1 and $1 \mathrm{~mm}$

\footnotetext{
12 The Yucca Mountain story is taken from Metlay (2000).
} 
per year, an uncertainty range that was reinforced by additional studies over the next 12 years. These estimates, based on combinations of expert judgment, numerical models, and laboratory experiments, were a crucial input for integrated performance assessment models of overall repository site behavior. Indeed, the $0.1-1 \mathrm{~mm}$ per year range allowed such performance assessments to conclude that the site was sufficiently dry to meet safety standards set by the US Environmental Protection Agency. As a result of this combined scientific stability and political desirability, by the mid-1990s, "thinking about percolation flux had almost achieved the status of conventional wisdom" (Metlay, 2000, p. 210).

However, the Yucca Mountain site was the focus of intense political controversy, and the scientific results that issued from the Department of Energy (DoE), which had responsibility for the site, were under constant fire. DoE was also subject to the oversight of two external bodies that reviewed the science and made recommendations for further research..$^{13}$ In this politically contentious environment, DoE was pushed to drill a tunnel that would enable direct sampling of rocks at the actual level of the proposed repository. Subsequent analysis of water in those rocks indicated the presence of radioactive isotopes generated from atmospheric nuclear weapons tests in the early years of the Cold War. That water containing these isotopes had made it from the surface to the repository site- 300 meters beneath the surface-in less than 50 years was evidence that percolation flux was perhaps ten times faster than indicated in modeling studies over the previous decade. Following this discovery, an aggregation of estimates from seven outside experts concluded that the $95 \%$ probability range for percolation flux lay between 1 and $30 \mathrm{~mm}$ per year-far higher rates than were encompassed by the "conventional wisdom" born during the prior decade or more of research. To complicate the story even further, efforts to reproduce the isotopic analysis of the repository water have yielded highly inconsistent results (Nuclear Waste Technical Review Board, 2000). After 20 years of research, uncertainties surrounding percolation flux seem only to have increased.

A key aspect of this story is that the decade or more of research reinforcing the belief that percolation flux lay between 0.1 and $1 \mathrm{~mm}$ per year was sponsored by the agency which had general responsibility for developing the repository site and strong institutional and political motivations to keep the project moving forward. As Metlay (2000, p. 211) observed, "when faced with the need to resolve uncertainty about percolation flux, the scientists [at DoE laboratories] had little organizational incentive to settle on a higher value or, more important, to question whether a lower value was correct. This approach to addressing uncertainty need not have been adopted consciously; in fact, it probably was not. More likely, it arose simply because organizational norms

\footnotetext{
13 These bodies were the Nuclear Waste Technical Review Board, an independent government agency, and the nongovernmental Board on Radioactive Waste Management of the National Research Council.
}

and culture have a well-documented and pervasive effect on individuals' actions and judgments." 14 Moreover, initial estimates of percolation flux emerged from an organizational and scientific context that was relatively homogeneous in terms of both scientific and political goals. As the research process opened up to more diverse scientific and political players, a greater diversity of values of interests were implicated, leading to the introduction of new sources of uncertainty.

\subsection{Climate change}

In climate change science, one closely scrutinized area of uncertainty is climate sensitivity, or the average global temperature increase associated with a doubling of atmospheric carbon dioxide. More than a century ago the Swedish chemist Arrhenius estimated this value at $5.5^{\circ} \mathrm{C}$ (Rayner, 2000), a number remarkably close to the likely temperature range of $1.5-4.5^{\circ} \mathrm{C}$ estimated by modern climate scientists using highly sophisticated numerical models, and adopted by the Intergovernmental Panel on Climate Change (IPCC) (Houghton et al., 2001, p. 67). While this latter temperature spread is very commonly used as an indication of the uncertainty range associated with climate sensitivity, the spread itself is not a probability range - that is, the probability of any particular temperature increase within this range is unspecified (as is the probability of the doubling temperature falling outside this range). Rather, the uncertainty range purportedly reflects the difference between the smallest and largest predicted temperature increases generated by a suite of 15 climate models (Houghton et al., 2001, p. 561). Yet, as van der Sluijs et al. (1998) have pointed out, a notable attribute of the canonical, IPCC-endorsed uncertainty range is that, for more than two decades, it has not changed, despite huge increases in the sophistication of climate models over that time - a fact that they explain in terms of an ongoing process of evolving judgment and negotiation among climate modelers working in a politically heated area of science, where significant changes in scientific conclusions could have considerable political repercussions.

Outside the IPCC process, however, the uncertainty associated with climate sensitivity has been expressed in several different ways. One effort (Morgan and Keith, 1995) elicited probabilities from 16 climate experts, and arrived

\footnotetext{
${ }^{14}$ A similar dynamic has been demonstrated in the area of clinical medical trials, where a number of studies have shown that trials directly or indirectly supported by pharmaceutical companies often yield more favorable assessments of new therapies-greater certainty about positive results - than trials that are not tied to the private sector in any way. The point here is not that scientists are engaging in fraudulent research in an effort to bolster a desired conclusion. The reality seems to be more interesting - that "close and remunerative collaboration with a company naturally creates goodwill [that] can subtly influence scientific judgment in ways that may be difficult to discern" (Angell, 2000, p. 1517). This conclusion is similar to Metlay's suggestion that "organizational norms and culture" influenced uncertainty estimates at Yucca Mountain.
} 
at a mean sensitivity of $2.6^{\circ} \mathrm{C}$ with a mean standard deviation of $1.4{ }^{\circ} \mathrm{C}$. This type of "subjective probability" presumes that all experts are providing equally "probable" estimates. Another method estimates climate sensitivity based on a simple climate/ocean model that simulates the observed hemispheric-mean near-surface temperature changes for the past century or so (Andronova and Schlesinger, 2001). This approach concludes that the $90 \%$ confidence interval for climate sensitivity is $1.0-9.3{ }^{\circ} \mathrm{C}$-much wider than the more familiar model uncertainty spread used by the IPCC. Other recent studies (Knutti et al., 2002; Forest et al., 2002) also indicate considerably wider spreads than the IPCC estimate. Thus, as in the Yucca Mountain case, an expansion of the institutional and scientific players destabilizes estimates of uncertainty.

This phenomenon threatens the claim that scientific research will help resolve scientific controversy through reduction of uncertainty. My own experience on the Climate Research Committee of the National Research Council illustrates how institutions central to the mainstream of scientific research may nevertheless seek to buttress this claim. During 2001-2003 I was part of a panel writing a report that was originally to be entitled Climate Change Feedbacks: Characterizing and Reducing Uncertainties. The panel's formal tasks in the report were to:

(1) characterize the uncertainty associated with climate change feedbacks ${ }^{15}$ that are important for projecting the evolution of the Earth's climate over the next 100 years; and

(2) define a research strategy to reduce the uncertainty associated with these feedbacks ....

Because the report was to deal directly with the problem of uncertainty in climate science, the panel decided to include a section discussing some of the complexities surrounding the concept of uncertainty in science and policy. This decision was particularly notable because such an approach had not been taken before. Numerous previous NRC reports on climate science, while frequently using the word "uncertainty," and asserting the importance of reducing it, did not make a serious effort to distinguish among the various meanings of the word, even while repeatedly making the claim that more research would reduce uncertainty, and reduced uncertainty would aid policy makers. ${ }^{16}$

A draft of the report was circulated to outside reviewers. The draft included a brief discussion of the concept of uncertainty, illustrated by a discussion of differing approaches

\footnotetext{
15 Climate feedbacks are processes in the climate system that can either magnify or reduce the system's response to climate forcing such as greenhouse gas emissions.

16 Perhaps most notable among these was the massive Pathways report, which states on its opening page (NRC, 1999a, p. 1), first that "we can now focus attention on the critical unanswered scientific questions that must be resolved to fully understand and usefully predict global change," and therefore, that "we need to reduce uncertainties in the projections that shape our decisions for the future."
}

to estimating the uncertainty associated with climate sensitivity. The draft also included the statements that "characterizing the uncertainty is not the same as reducing it," and that "there is no guarantee that further research will soon reduce the uncertainty in climate projections." 17

Reviewers were extremely critical of this discussion, noting especially that the word "uncertainty" was used in many different ways without clearly defining them. "This is not a trivial issue," one reviewer acutely noted, "because it is a matter of objectives. Each definition of uncertainty represents a different definition of objectives, which leads to a different definition of metrics." Reviewers also strongly criticized the report's focus on "model uncertainty," which was deemed "unacceptable for institutional reasons. It states the objective of a multibillion dollar program in strictly insider's terms, i.e., understandable and of interest only to scientists, and makes a point of saying that societal links cannot be established." 18

Yet the reviewers did not suggest that a revised draft include a more careful definition and delineation of the various uses of the word "uncertainty," but rather recommended the opposite-that the specific discussion of uncertainty be omitted. This seems to indicate that the problem was not the various meanings and uses of the word throughout the report, but the calling attention to them in the introductory discussion. Indeed, prior NRC climate reports also used "uncertainty" in a similar variety of ways without defining or distinguishing them (e.g., NRC, 1999a; NRC, 2000; NRC, 2001).

The panel's subsequent set of revisions included a very reduced section on uncertainty, but did not eliminate the discussion of climate sensitivity, which was felt to be an important illustration of how uncertainty could be characterized in different ways. Statements about the difficulties of reducing uncertainty were also left in. Reviewers again objected, and it was made clear to the panel that unless the offending language was removed, the report would not be published. ${ }^{19}$ Thus, in the final report all discussion of uncertainty was removed. Even the word "uncertainty" was stripped from the title, which was changed to Understanding Climate Change Feedbacks (NRC, 2003). The multiplicities of meaning and use of the word "uncertainty" remain (unacknowledged) in the report, ${ }^{20}$ as does the promise, both

\footnotetext{
17 Quotes from a 6 June 2002 draft of the report.

18 Quotes from an 8 August 2002 internal memo to the panel from NRC staff.

19 Memo to the panel, 9 July 2003.

${ }^{20}$ As just one example: in a discussion of cloud feedbacks, successive paragraphs refer first to "reduction in the uncertainty of climate sensitivity," which is generally reported as a model uncertainty, and then states that "[a]nother key uncertainty in cloud-climate interactions is the response of anvil clouds to surface temperature." The second use of the word seems simply to mean "incomplete knowledge" (NRC, 2003, p. 27). Two pages later "uncertainty" is used to mean the difficulty of quantifying a specific value ("the amount of radioactive heating that occurs within the atmosphere versus how much heating occurs at the surface ...") (NRC, 2003, p. 30)
} 
explicit and implicit, that more research, and better models, will reduce uncertainties. ${ }^{21}$ Absent, however, is any discussion of these issues.

The conspicuous contradiction between the reviewers' comments and their suggested changes makes it very difficult to understand the review process as anything other than an effort to reinforce what Shackley and Wynne (1996, p. 285) termed the "condensation" of uncertainty's many meanings and complexities into "one undifferentiated category" that allows broad claims to be made about how the key to a given problem is more research and more time. Moreover, by presenting uncertainty as a vague but putatively coherent concept that is "reduced" through more research, the scientific community assures that the phenomenon of uncertainty remains located in our imperfect (but always-improving) understanding of nature, and is not an attribute of nature itself, of the structure of disciplinary science, or of the social and political context within which research is conducted. In this way, scientists can maintain control over the management of uncertainty while also, in the words of Shackley and Wynne (1996, p. 287), "strengthening the authority of science [that] in turn reinforces a particular policy order."

As it pertains to environmental controversy, the word "uncertainty" refers most generally to the disparity between what is known and what actually is or will be. Uncertainty, that is, reflects our incomplete and imperfect characterization of current conditions relevant to an environmental problem, and our incomplete and imperfect knowledge of the future consequences of these conditions. For a well bounded problem, these insufficiencies can to some extent be addressed (although never eliminated) through additional research, but there are many reasons why such an approach might not succeed, for example, when additional research reveals heretofore unknown complexities in natural systems, or highlights the differences between competing disciplinary perspectives, and thus expands the realm of what is known to be unknown.

But as the previous examples show, the characterization of uncertainty also reflects the political and institutional contexts within which science is conducted and debated, the diversity of scientific practice, and the psychological states of those making the characterizations. ${ }^{22}$ Uncertainty is in part a manifestation of the disunity of science and the plurality of institutional and political players (and their competing value commitments) involved in the conduct and interpretation of

\footnotetext{
${ }^{21}$ For example, "Research into carbon uptake by the land and ocean as outlined in the US Carbon Cycle Plan ... should be undertaken to characterize and reduce the uncertainty associated with carbon uptake feedbacks" (NRC, 2003, p. 10).

${ }^{22}$ For example, the propensity of experts to display overconfidence in probability estimates has long been recognized (Kahneman et al., 1982). Moreover, as Rosenberg (1994) points out, the very act of estimating probabilities increases the complexity of the system being studied because that system now includes the cognitive states of the experts who are doing the estimating.
}

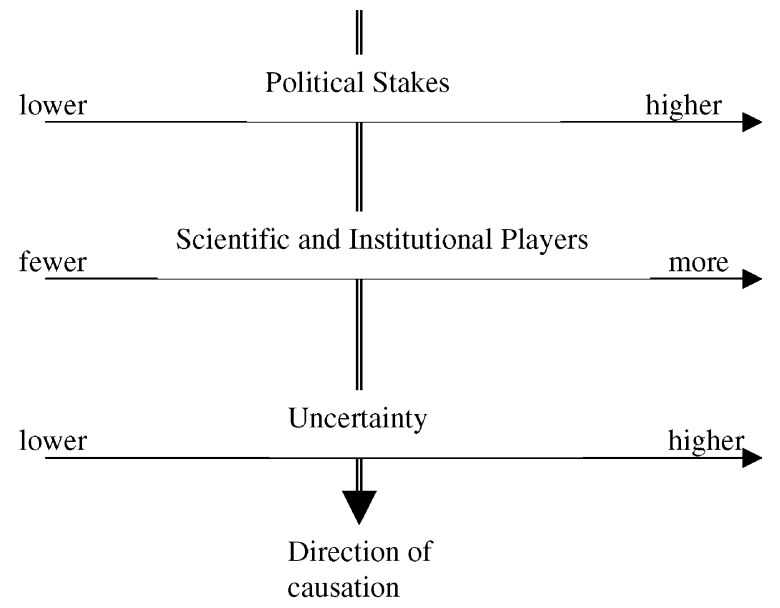

Fig. 1. Schematic illustration of influence of political context on level of uncertainty.

scientific research. It is the location where conflicts between competing sets of facts and disciplinary perspectives reside.

One simple way to think about these relations is shown in Fig. 1. When political stakes associated with a controversy are relatively low, high certainty is more permissible than when the stakes are high (e.g., Collingridge and Reeve, 1986). Fewer disciplines, institutions, and stakeholders are likely to have strong and competing interests in any particular assertion of uncertainty levels. This relation is illustrated by the Parkfield prediction. But when the costs and benefits associated with action on a controversy begin to emerge and implicate a variety of interests, both political and scientific scrutiny of the problem will increase, as will sources of uncertainty, as shown by the climate sensitivity and nuclear waste cases. ${ }^{23}$ Moreover, when political controversy exists, the whole idea of "reducing uncertainty" through more research is incoherent because there will never be a single problem for which a single, optimizable research strategy or solution path can be identified, let alone characterized through a single approach to determining uncertainty. Instead, there will be many different problems defined in terms of many competing value frameworks and studied via many disciplinary approaches.

Recent developments in the Yucca Mountain story starkly illustrate the implications of these observations. In July 2002 President Bush signed a Congressional resolution that allows the US Department of Energy to apply for a license to actually construct the nuclear waste repository at Yucca Mountain (Holt, 2003). This crucial political step was taken even though uncertainty about site behavior has increased significantly in recent years, due both to controversy over the hydrogeology, discussed above, and new insights into the effects of corrosion on waste containment vessels (Nuclear

\footnotetext{
23 Jamieson (1995, p. 37) has made a similar point in arguing that "[r]ather than being a cause of controversy, scientific uncertainty is often a consequence of controversy." However Shackley and Wynne (1996, p. 276) suggested the opposite- that "the less a science is tied to policy uses, the more its practitioners would be free to express uncertainty."
} 
Waste Technical Review Board, 2003). What allowed political action to take place was the consolidation of national political power in the hands of the Republican party, which is sympathetic to the interests of the nuclear power industry, and thus supports moving ahead with development of the waste site. The diversity of political interests controlling the decision process was curtailed, and as a result the optimistic views on uncertainty of scientists and bureaucrats at the Department of Energy were able to prevail over other perspectives and interests. While these events are unlikely to mark an end to the controversy, they can allow action to proceed, and thus mark the beginning of what Schön and Rein (1994, p. xix) have called a "policy drama," where the discussion increasingly focuses on assessing progress toward a particular goal, e.g., the safe storage of nuclear waste, rather than on impossible-to-resolve questions such as whether "safe" storage is possible.

\section{Why scientize?}

The organization of science-its methodological and disciplinary diversity; the multiple institutional settings in which it is conducted-make it a remarkably potent catalyst for political dispute. Recognizing that simple, linear formulations leading from "more science" to "less uncertainty" to "political action" are inherently flawed, others have suggested that society needs to adopt new ways of thinking about the conduct of science, new ways of evaluating how and when science is valid or potentially useful, new institutions for mediating the processes by which science is integrated into political decision making, and new geographic and temporal scales for conducting and using science (e.g., Funtowicz and Ravetz, 1992; Gallopín et al., 2001; Lee, 1993; Nowotny et al., 2001; Gibbons, 1999; NRC, 1999b; Jasanoff, 1990, 1996b). While accepting the value and salience of all of these suggestions, they focus on the problem of understanding how scientific knowledge, in all its multifarious, social complexity, can best be integrated into contentious decision making processes. In cases where problems are fairly well circumscribed in terms of institutional players and problem definition, such approaches may make particular sense. Yet they do not engage this overarching observation: we have few good examples of science providing sufficient clarification to point the way through politically charged, open-ended environmental controversies, ${ }^{24}$ yet in-

\footnotetext{
${ }^{24}$ The successful negotiation of the Montreal Protocol, mandating the phase out of stratospheric-ozone-depleting chlorofluorocarbons (CFCs), is the most obvious candidate for such a success story. The identification of a single chemical culprit (CFCs) as the major cause of ozone depletion suggests that this problem was scientifically "easier" than other high-profile controversies. Yet the incentives for policy action were strongly enhanced by a political and diplomatic climate that was receptive to reductions in CFC use even before the resolution of the major scientific questions about ozone depletion (Benedick, 1991; Sarewitz, 1996). Also important was the invention of CFC alternatives by DuPont (Rowlands, 1993), which
}

numerable examples of decisive political action in all realms of society taken despite controversy and uncertainty, and with science playing little or no formal role in the debate. One must wonder if it is worth approaching the problem from the opposite direction. So I would like to conclude by briefly exploring the following question: why is it that some political controversies become scientized, while others do not?

To return to the 2000 Presidential election, on its face, the vote count should have been much more amenable to scientific investigation and uncertainty reduction than even the simplest environmental controversy. On the other hand, the election was broadly accepted as a relatively pure process for adjudicating competing values and interests. Moreover, those values and interests had been on public display for months through the election campaign process. Even though the adjudication process itself was a technical one (counting votes), once the authoritativeness of that process was called into question, numerous other mechanisms for adjudicating value disputes were available and mobilized. Because these mechanisms were unabashedly political (or, in the case of the US Supreme Court, perhaps abashedly so), they were not subject to criticism for using junk science or for politicizing scientific results. Contesting sides were overtly seeking to advance their own interests. If there are complaints to be made about this process, they must address the mechanisms by which interests are advanced, such as campaign financing or the process of selecting judges, rather than the mechanism by which the controversy was ended.

What are the interests and values at stake in controversies over global climate change, nuclear waste disposal, or genetically modified foods? While it may not be very hard to arrive at plausible hypotheses about the value preferences of people holding various positions in such controversies, the scientific debate itself conceals those preferences behind technical arguments. This camouflaging process reflects, in part at least, the enduring social commitment to the idea of scientific facts as detached from values, and the consequent desire of everyone on all sides of a given controversy to legitimate their value preferences with an allegedly independent body of facts (e.g., Nelkin, 1995). This commitment is codified through a variety institutions and agreements, for example, the Intergovernmental Panel on Climate Change, which is supposed to provide the scientific basis for making international decisions about climate, and the World Trade Organization, which allows nations to regulate trade in agricultural goods based on risks to human, animal, and plant health only if such regulation is based on accepted scientific principles and standards (World Trade Organization, 1995). What Wynne (1991, p. 120) observed more than a decade ago seems to be no less true today: despite the policy implications of scholarly insight into the contextual origins

\footnotetext{
allowed private sector interests to align with calls for a CFC phase out. The ozone story is less one of controversy resolved by science than of positive feedback among convergent scientific, political, diplomatic, and technological trends.
} 
of scientific knowledge, "the overall trend in the structure and control of science is currently running in the opposite direction."

Any political decision (indeed, any decision) is guided by expectations of the future. Such expectations can in turn be less or more informed by technical knowledge, but the capacity of such knowledge to yield an accurate and coherent picture of future outcomes is very limited indeed. Ultimately, most important decisions in the real world are made with a high degree of uncertainty, but are justified by a high level of commitment to a set of goals and values. Such past political acts as the passage of civil rights legislation, the reform of the US welfare system, or the decision to invade Iraq were not taken on the basis of predictive accuracy or scientific justifications about what the future would look like, but on the basis of convictions about what the future should look like, informed by plausible expectations of what the future could look like. From this perspective it is useful to recall that, when comprehensive environmental laws were enacted in the US during the late 1960s and early 1970s, scientific knowledge about the state of the environment was much less comprehensive and sophisticated than it is today, when almost all environmental laws and regulations are under political attack. The implementation of a broad legal framework for environmental protection in the US was a response to a social and political consensus, not authoritative knowledge (e.g., Kraft and Vig, 1997).

It is difficult to avoid the conclusion that there is no a priori reason why some types of political controversies should be highly scientized, and others should not be. For example, from a purely technical standpoint, the difficulties of predicting future climate outcomes and impacts over the next century, or predicting the behavior of a nuclear waste site over the next 10,000 years, cannot be much less complex, and are likely much more complex, than predicting the future of, say, different immigration policies or medical insurance systems.

Why, then, do some controversies become more scientized than others? Possibilities include:

1. advocates or opponents of action believe that scientific knowledge will advance their value positions or interests;

2. advocates or opponents of action believe that scientific uncertainty will advance their value positions or interests;

3. scientists are involved in the political framing of the controversy; and

4. available policy options for addressing the controversy are insufficiently broad or appealing to attract a political consensus.

In contrast, reasons why some controversies do not become highly scientized might include:

1. value positions are well articulated from the beginning of the controversy;

2. values underlying the controversy are widely viewed as inappropriate for scientific adjudication;
3. effective mechanisms for eliciting and adjudicating value disputes are already in place and well-accepted; and

4. available policy options are broad and appealing enough to attract a political consensus.

Political decision making can fruitfully be understood as a process of adjudicating value disputes (Lasswell, 1977, pp. 184-185; Sandel, 1996, pp. 17-18). This understanding certainly does not imply that facts have no place in political debate. People can only make sense of the world by finding ways to reconcile their beliefs with some set of facts about how reality must operate (e.g., Simon, 1983; Schön and Rein, 1994). So politics can isolate values from facts no more than science can isolate facts from values. The nature of this interaction has been a central subject of science studies scholarship (e.g., Jasanoff, 1987; Jasanoff, 1990).

The problem is that this symmetry does not manifest in political processes. Political debate permits the mobilization of a broad range of weaponry, including scientific facts, religious dogma, cultural norms, and personal experience, in defense of one's values and interests. But scientized debate must suppress the open discussion of value preferences; were it not to do so it would have no claim to distinction from politics. ${ }^{25}$ This need can strike at the heart of democratic vitality. For example, as mentioned, World Trade Organization rules require that nations can only restrict trade in genetically modified foods on the basis of scientific risk assessments. These rules, of course, are meant to ensure a more open flow of goods across national boundaries, and thus give precedence to economic values over all others. But the well documented opposition in many European countries to GM foods appears to have little to do with scientifically determined levels of risk, and much to do with non-economic values. In many European nations, a majority of people surveyed say that they would not purchase GM foods even if they were known to be safe, environmentally friendly, and cheaper than non-GM equivalents. Survey data show that people's concerns are related more to a desire for transparency in decision making about GM foods, a suspicion about the economic motives of multinational companies who sell such foods, a concern about the implications of GM products for the European agricultural system (which in turn connects to concerns about landscape and culture), and worries about the implications of globalization for quality of life (Marris et al., 2001; Gaskell et al., 2003; Rayner, 2003). In the scientized controversy over GM foods, these diverse values have no legitimated part in the debate over levels of risk. Thus, not only are expressions of these values suppressed, but they are suppressed in favor of an alternative value-economic openness - that remains camouflaged

\footnotetext{
25 In reality, of course, scientists are constantly engaged in a process of sub rosa, perhaps even subconscious, negotiation that is unavoidably political, whether working in the closed context of a research community (e.g., Fleck, 1979; Collins, 1985), or in the more highly charged atmosphere of a science advisory panel (Jasanoff, 1990).
} 
behind the commitment to carrying out the debate in scientific terms alone.

Scientization of controversy also undermines the social value of science itself. In the absence of agreed upon values that can inform the articulation of social goals, we cannot recognize the broad range of policy options that might be available to achieve those goals, nor can we possibly know how to prioritize scientific research in support of the goals. ${ }^{26}$ Scientific resources end up focused on the meaningless task of reducing uncertainties pertinent to political dispute, rather than addressing societal problems as identified through open political processes. The opportunity cost may be huge. ${ }^{27}$ Consider what has taken place in the climate change arena. Certainly the Kyoto Protocol stands as the most significant political achievement related to climate change thus far. The Protocol represents the translation of a set of scientific insights about the relation between greenhouse gas emissions and global temperatures into a political decision to take a first step toward reducing those emissions. ${ }^{28}$ But no one can possibly know what the consequences of these emissions reductions will be, either in terms of climate behavior or socioeconomic outcomes. Thus, the only coherent value that can be extracted from the decision to adopt such reductions is that reducing greenhouse gas emissions is an inherently good thing to do. But this raises its own set of problems. The Kyoto goals could be achieved, for example, through a variable combination of emissions and sequestration schemes, which might or might not actually result in decreased hydrocarbon consumption. They could be pursued by enhancing global economic equity, for example, through diffusion of new technologies, or by further concentrating global wealth, for example, through policies that fail to spur economic development in poor countries (thus keeping energy consumption low). ${ }^{29}$ And the pursuit of the Kyoto goals is not likely to have any discernible effect at all on the impacts of climate on society. If concerns about the negative impacts of climate change are a motivating value behind emissions reductions, those concerns will not be met.

Were such goals and values as, say, absolute reductions in hydrocarbon consumption through greater energy efficiency, more equitable global economic development, and

\footnotetext{
26 Some environmental controversies, such as climate change, only exist because of scientific research that allowed the problem to be recognized in the first place. However, the role of bringing an environmental problem to public attention is not at all the same as resolving the value-based controversies raised by the problem (e.g., Herrick and Sarewitz, 2000; Alario and Brün, 2001).

27 As one indication of this opportunity cost, consider that the US federal commitment to basic research on climate change has been about four times more than its expenditures on renewable energy research (EIA, 2001).

28 That is, for industrialized nations, by $5 \%$ below 1990 levels by the year 2012.

29 In this light it is notable that the Kyoto Protocol's relatively modest commitment to technology development and diffusion is more than offset by a variety of economic and technology policies endorsed by many signatory nations that increasingly undermine the development prospects of poor countries (e.g., Stiglitz, 2003).
}

decreased impacts of climate on society openly adopted as worthy of pursuit by society with the help of science, then global scientific priorities would look considerably different than they do now (e.g., Sarewitz and Pielke, 2000; Pielke and Sarewitz, 2003), perhaps corresponding more closely to what some have termed "sustainability science" (NRC, 1999b; Kates et al., 2001).

From these brief discussions I hope to have made clear that there is no reason why environmental controversies must be highly "scientized." Even if science brings such a controversy into focus (for example, by documenting a rise in atmospheric greenhouse gases), the controversy itself exists only because conflict over values and interests also exists. Bringing the value disputes concealed by - and embodied in-science into the foreground of political process is likely to be a crucial factor in turning such controversies into successful democratic action, and perhaps as well for stimulating the evolution of new values that reflect the global environmental context in which humanity now finds itself (Jamieson, 1992). Moreover, the social value of science itself is likely to increase if scientific resources relevant to a particular controversy are allocated after these value disputes have been brought out into the open, their implications for society explored, and suitable goals identified. ${ }^{30}$

A variety of researchers have sought to develop methods for integrating values into environmental research, for example, by developing scenarios of the future evolution of environment and society that respond to different sets of value preferences (e.g., van Asselt and Rotmans, 1996; Rotmans and De Vries, 1997; Costanza, 2000; UK Climate Impacts Programme, 2001). It is not clear whether or not this is a step in the right direction because these approaches still depend on the ability of mathematical models to yield plausible scenarios of the future, where plausibility will in part be judged within the normative perspectives of those using the models (which themselves embody the normative perspectives of those who build the models). Moreover, the process of articulating concrete future alternatives through models could have the affect of exacerbating political controversy by claiming to make it clearer who future winners and losers are likely to be, given a set of decisions and predicted outcomes (e.g., Glantz, 1995). These approaches also beg the question of how values will actually be elicited and adjudicated in choosing what scenarios society should actually pursue.

What I am suggesting is that progress in addressing environmental controversies will need to come primarily from advances in political process, rather than scientific research. Perhaps such advances will require the formal or informal imposition of a sort of "quiet period" for scientific debate

\footnotetext{
30 At this point I must, unfortunately, emphasize that this is neither a brief for nor against "basic research." There is, indeed, every reason to believe that the political determination of value preferences and goals in the realm of the environment would need to be followed by research of many different kinds aimed at helping to pursue those goals.
} 
when environmental controversies become highly publicized and gridlocked, to create time and space for underlying value disputes to be brought into the open, explored, and adjudicated as such in democratic fora. During such a "quiet period," those who make scientific assertions in fora of public deliberation would have to accompany those claims with a statement of value preferences and private interests relevant to the dispute. This rule would be enforced for scientists as well as lay people. Science does not thereby disappear from the scene, of course, but it takes its rightful place as one among a plurality of cultural factors that help determine how people frame a particular problem or position-it is a part of the cognitive ether, and the claim to special authority vanishes.

If this suggestion seems not just playful but frivolous, consider where my discussion began, with the election and Lomborg controversies. In the former case, the factual dispute was subjugated to the practical necessity of arriving at a resolution, and politics was allowed to do its job. In the latter case, an insistence by all parties that the dispute is about who is in charge of the right environmental facts merely recapitulates in miniature the escalating political gridlock surrounding environmental politics. The technical debate-and the implicit promise that "more research" will tell us what to do-vitiates the will to act. Not only does the value dispute remain unresolved, but the underlying problem remains unaddressed.

The point is not that stripping away the overlay of scientific debate must force politicians to take action. But if they choose not to act they can no longer claim that they are waiting for the results of the next round of research - they must instead explain their allegiance to inaction in terms of their own values and interests, and accountability now lies with them, not with science or scientists. To the extent that our democratic political fora are incapable of enforcing that accountability, the solution must lie in political reform, not more and better scientific information.

Yet one question remains: what, then, becomes of science? One part of the answer is: nothing, it is still there, in the background, along with all the other influences on people's political interests and behavior. But the other part of the answer is that science is liberated to serve society and the environment, for, as I have suggested, it is only after values are clarified and some goals agreed upon that appropriate decisions about science priorities can emerge.

No longer able to hide behind scientific controversy, politics would have to engage in processes of persuasion, reframing, disaggregation, and devolution, to locate areas of value consensus, overlapping interests, or low-stakes options (e.g., "no regrets" strategies) that can enable action in the absence of a comprehensive political solution or scientific understanding (Sarewitz and Pielke, 2000; Pielke and Sarewitz, 2003). In particular, the abandonment of a political quest for definitive, predictive knowledge ought to encourage, or at least be compatible with, more modest, iterative, incremental approaches to decision making that can facilitate consensus and action. Such approaches call upon science not to be a predictive oracle to guide policy choices, but a tool to support, monitor, and assess the implementation of policies that have been selected through the political process (Brunner, 2000; Herrick and Sarewitz, 2000; Lee, 1993). "Sustainability," write Rayner and Malone (1998, p. 132) "is about being nimble, not being right." And being nimble is about taking small steps and keeping one's eyes open. Politics helps us decide the direction to step; science helps the eyes to focus.

\section{Acknowledgements}

Roger Pielke Jr., Beth Raps, Richard Nelson, Charles Herrick, and Naomi Oreskes provided valuable comments on this paper. I also thank three anonymous reviewers for their extraordinarily penetrating critiques of the penultimate version (to the numerous arguments against anonymity in peer review, add this: one is deprived of the pleasure and benefit of continued engagement with thoughtful reviewers). Discussions with Daniel Metlay have contributed greatly to my understanding of the Yucca Mountain story, as well as to the broader question of how institutions confront uncertainty.

\section{References}

Alario, A., Brün, M., 2001. Uncertainty and controversy in the science and ethics of environmental policy making. Theory Sci. 2 (1), http://theoryandscience.icaap.org/content/vol002.001/02alariobrun.html

Andronova, N., Schlesinger, M.E., 2001. Objective estimation of the probability distribution for climate sensitivity. J. Geophys. Res. 106 (D19), 22605-22612.

Angell, M., 2000. Is academic medicine for sale? N. Engl. J. Med. 342 (20), 1516-1518.

Ausubel, J., 1991. Energy and environment: the light path. Energy Syst. Policy 15, 181-189.

Bakun, W.H., Lindh, A.G., 1985. The Parkfield, California, earthquake prediction experiment. Science 229, 619-624.

Barke, R., Jenkins-Smith, H., 1993. Politics and scientific expertise: scientists, risk perception, and nuclear waste policy. Risk Anal. 13, 425-439.

Benedick, R., 1991. Protecting the ozone layer: new directions in diplomacy. In: Mathews, J.T. (Ed.), Preserving the Global Environment: The Challenge of Shared Leadership. W.W. Norton, New York.

Bowker, G., Star, S.L., 2001. Pure, real and rational numbers: the American imaginary of countability. Social Stud. Sci. 31 (3), 422-425.

Brunner, R., 2000. Alternatives to prediction. In: Sarewitz, D., Pielke Jr., R.A., Byerly Jr., R. (Eds.), Prediction: Science, Decision Making, and the Future of Nature. Island Press, Covelo, CA, pp. 299-313.

Cartwright, N., 1999. The Dappled World, A Study of the Boundaries of Science. Cambridge University Press, Cambridge, UK.

Changnon, S.A., Pielke Jr., R.A., Changnon, D., Sylves, R.T., Pulwarty, R., 2001. Human factors explain the increased losses from weather and climate extremes. Bull. Am. Meteorol. Soc. 81 (3), 437-442.

Chichilnisky, G., Heal, G., 1995. Markets for tradable $\mathrm{CO}_{2}$ emission quotas principles and practice. OECD Economics Department Working Papers No. 153, OCDE/GD(95)9, Organization for Economic Co-Operation and Development, Paris.

Climate Change Science Program, 2003. Strategic Plan for the US Climate Change Science Program. Climate Change Science Program, Washington, DC. 
Collingridge, D., Reeve, C., 1986. Science Speaks to Power: The Role of Experts in Policy. St. Martin's Press, New York.

Collins, H., 1985. Changing Order: Replication and Induction in Scientific Practices. Sage, London.

Costanza, R., 2000. Visions of alternative (unpredictable) futures and their use in policy analysis. Conserv. Ecol. Online 4 (1), http://www.ecologyandsociety.org/vol4/iss1/art5/index.html.

Dupré, J., 1993. The Disorder of Things, Metaphysical Foundations of the Disunity of Science. Harvard University Press, Cambridge, MA.

The Economist Print Edition, 2003. Hot potato revisited. Economist November, 76.

EIA (Energy Information Agency), 2001. Renewable energy 2000: issues and trends. Available at www.eia.doe.gov/cneaf/solar.renewables/ rea_issues/reatabp2.html.

Ezrahi, Y., 1990. The Descent of Icarus: Science and the Transformation of Contemporary Democracy. Cambridge University Press, Cambridge, MA.

Fleck, L., 1979. Genesis and Development of a Scientific Fact. University of Chicago Press, Chicago (original published in 1935).

Food and Agriculture Organization of the United Nations, 2003a. Weighing the GMO arguments: against. Available at http://www.fao. org/english/newsroom/focus/2003/gmo8.htm.

Food and Agriculture Organization of the United Nations, 2003. Weighing the GMO arguments. Available at http://www.fao.org/ english/newsroom/focus/2003/gmo7.htm.

Forest, C.E., Stone, P.H., Sokolov, A.P., Allen, M.R., Webster, M.D., 2002. Quantifying uncertainties in climate system properties with the use of recent climate observations. Science 295, 113-117.

Funtowicz, S.O., Ravetz, J.R., 1992. Three types of risk assessment and the emergence of post-normal science. In: Krimsky, S., Golding, D. (Eds.), Social Theories of Risk. Praeger, Westport, CT, pp. 251-273.

Gallopín, G.C., Funtowicz, S., O'Connor, M., Ravetz, J., 2001. Science for the twenty-first century: from social contract to the scientific core. Int. Social Sci. J. 53, 219-229.

Gaskell, G., Allum, N., Stares, S., 2003. Europeans and biotechnology in 2002. A report to the EC Directorate General for Research from the project 'Life Sciences in European Society', QLG7-CT-1999-00286, http://europa.eu.int/comm/public_opinion/archives/eb/ebs_177_en.pdf.

Gibbons, M., 1999. Science's new social contract with society. Nature 402 (Suppl.), C81-C84.

Glantz, M.H., 1995. Assessing the impacts of climate: the issue of winners and losers in a global climate change context. In: Zwerver, S., van Rompaey, R.S.A.R., Kok, M.T.J., Berk, M.M. (Eds.), Climate Change Research: Evaluation and Policy Implications. Elsevier, Amsterdam.

Gough, M., 2003. Politicizing Science. Hoover Institution Press, Stanford, CA.

Harrison, C., 2004. Peer review, politics and pluralism. Environ. Sci. Policy 7 (5), 357-368.

Heron, M.C., Sekhon, J.S., 2003. Overvoting and representation: and examination of overvoted presidential ballots in Broward and Miami-Dade counties. Electoral Stud. 22 (1), 21-47.

Herrick, C., Jamieson, D., 1995. The social construction of acid rain: some implications for science/policy assessment. Global Environ. Change 5, 105-112.

Herrick, C., Jamieson, D., 2001. Junk science and environmental policy: obscuring public debate with misleading discourse. Philosophy Public Policy Q. 21 (Spring), 11-16.

Herrick, C., Sarewitz, D., 2000. Ex post evaluation: a more effective role for scientific assessments in environmental policy. Sci. Technol. Hum. Values 25 (3), 309-331.

Holling, C.S., 1998. Two cultures of ecology. Conserv. Ecol. 2 (2), http://www.consecol.org/vol2/iss2/art4.

Holt, M., 2003. Civilian nuclear waste disposal. Congressional Research Service, Order Code IB92059, Washington, DC, http://www. NCSEonline.org/NLE/CRS/abstract.cfm?NLEid=17012.

Houghton, J.T., Ding, Y., Griggs, D.J., Noguer, M., van der Linden, P.J., Dai, X., Maskell, K., Johnson, C.A., 2001. Climate Change 2001:
The Scientific Basis. Contribution of Working Group I to the Third Assessment Report of the Intergovernmental Panel on Climate Change. Cambridge University Press, Cambridge, UK.

Hull, D.L., 1988. Science as a Process: An Evolutionary Account of the Social and Conceptual Development of Science. University of Chicago Press, Chicago.

Jamieson, D., 1992. Ethics, public policy, and global warming. Sci. Technol. Hum. Values 17 (2), 139-153.

Jamieson, D., 1995. Scientific uncertainty and the political process, annals. Am. Acad. Political Social Sci. 545, 35-43.

Jasanoff, S., 1987. Contested boundaries in policy-relevant science. Social Stud. Sci. 17 (2), 195-230.

Jasanoff, S., 1990. The Fifth Branch: Science Advisors as Policymakers. Harvard University Press, Cambridge, MA.

Jasanoff, S., 1996a. Beyond epistemology: relativism and engagement in the politics of science. Social Stud. Sci. 26 (2), 393-418.

Jasanoff, S., 1996b. The dilemma of environmental democracy. Issues Sci. Technol. 13 (1), 63-70.

Jasanoff, S., Wynne, B., 1998. Science and decision making. In: Rayner, S., Malone, E. (Eds.), Human Choice and Climate Change, vol. 1: The Societal Framework. Battelle Press, Columbus, OH, pp. 1-87.

Kagan, Y.Y., 1997. Statistical aspects of Parkfield earthquake sequence and Parkfield prediction experiment. Tectonophysics 270 (3-4), 207-219.

Kahneman, D., Slovic, P., Tversky, A., 1982. Judgment Under Uncertainty: Heuristics and Biases. Cambridge University Press, New York.

Kaiser, R.G., 2000. Is this any way to pick a winner. Washington Post 26 May, A1.

Kaplinsky, N., Braun, D., Lisch, D., Hay, A., Hake, S., Freeling, M., 2002. Maize trangene results in Mexico are artefacts. Nature 416, 601-602.

Kates, R.W., Clark, W.C., Corell, R., Hall, J.M., Jaeger, C.C., Lowe, I., McCarthy, J.J., Schellnhuber, H.J., Bolin, B., Dickson, N.M., Faucheux, S., Gallopin, G.C., Grübler, A., Huntley, B., Jäger, J., Jodha, N.S., Kasperson, R.E., Mabogunje, A., Matson, P., Mooney, H., Moore III, B., O'Riordan, T., Svedin, U., 2001. Sustainability science. Science 292 (5517), 641-642.

Kitcher, P., 2001. Science, Truth, and Democracy. Oxford University Press, New York.

Knutti, R., Stocker, T.F., Joos, F., Plattner, G.K., 2002. Constraints on radiative forcing and future climate change from observations and climate model ensembles. Nature 416, 719-723.

Kraft, M.E., Vig, N.J., 1997. Environmental policy from the 1970s to the 1990s: an overview. In: Vig, N.J., Kraft, M.E. (Eds.), Environmental Policy in the 1990s. CQ Press, Washington, DC, pp. 1-30.

Lasswell, H.D., 1977. Psychopathology and Politics. University of Chicago Press, Chicago.

Lee, K., 1993. Compass and Gyroscope, Integrating Science and Politics for the Environment. Island Press, Covelo, CA.

Leib, J.I., Dittmer, J., 2002. Florida's residual votes, voting technology and the 2000 election. Political Geography 21, 91-98.

Lepkowski, W., 2002a. Biotech's OK corral. Sci. Policy Perspect. 13, http://www.cspo.org/s\&pp/060902.html.

Lepkowski, W., 2002b. Maize, genes, and peer review. Sci. Policy Perspect. 14, http://www.cspo.org/spp/102502.html.

Lomborg, B., 2001. The Skeptical Environmentalist: Measuring the State of the Real World. Cambridge University Press, Cambridge, UK.

Lovejoy, T., 2002. Biodiversity: dismissing scientific process. Scientific American.com, January, http://www.sciam.com/article.cfm? articleID=000F3D47-C6D2-1CEB-93F6809EC5880000\&pageNumber $=12 \&$ cat ID $=2$.

Marland, G., Pielke Sr., R.A., Apps, M., Avissar, R., Betts, R.A., Davis, K.J., Frumhoff, P.C., Jackson, S.T., Joyce, L., Kauppi, P., Katzenberger, J., MacDicken, K.G., Neilson, R., Niles, J.O., Sutta, D., Niyogi, S., Norby, R.J., Pena, N., Sampson, N., Xue, Y., 2003. The climatic impacts of land surface change and carbon management, and the implications for climate-change mitigation policy. Climate Policy 3, 149-157.

Marris, C., Wynne, B., Simmons, P., Weldon, S., 2001. Public perceptions of agricultural biotechnologies in Europe. Final report of the PABE Research project, http://www.lancs.ac.uk/depts/ieppp/pabe/docs.htm. 
Merzer, M., 2001. "Overvotes" leaned to Gore. The Miami Herald.com, 11 May, http://www.miami.com/mld/miami/news/2067453.htm.

Metlay, D., 2000. From tin roof to torn wet blanket: predicting and observing groundwater movement at a proposed nuclear waste site. In: Sarewitz, D., Pielke Jr., R.A., Byerly Jr., R. (Eds.), Prediction: Science, Decision Making, and the Future of Nature. Island Press, Covelo, CA, pp. 199-228.

Metz, M., Fütterer, J., 2002. Suspect evidence of transgenic contamination. Nature 416, 600-601.

Michael, D.N., 1995. Barriers and bridges to learning in a turbulent human ecology. In: Gunderson, L., Holling, C., Light, S. (Eds.), Barriers and Bridges to the Renewal of Ecosystems and Institutions. Columbia University Press, New York, pp. 461-485.

Morgan, M.G., Keith, D.W., 1995. Subjective judgments by climate experts. Environ. Sci. Technol. 29, A468-A476.

Nakicenovic, N., 1996. Freeing energy from carbon. Daedalus 125 (3), 95-112.

Nature Publishing Group, 2002. Conflicts around a study of mexican crops. Nature 417, 897-898.

Nelkin, D., 1975. The political impact of technical expertise. Social Stud. Sci. 5 (1), 35-54.

Nelkin, D., 1979. Controversy: Politics of Technical Decisions. Sage, London.

Nelkin, D., 1995. Science controversies: the dynamics of public disputes in the United States. In: Jasanoff, S., Markle, G.E., Petersen, J., Pinch, T. (Eds.), Handbook of Science and Technology Studies. Sage, Thousand Oaks, CA, pp. 444-456.

Nigg, J., 2000. Predicting earthquakes: science, pseudoscience, and public policy paradox. In: Sarewitz, D., Pielke Jr., R.A., Byerly Jr., R. (Eds.), Prediction: Science, Decision Making, and the Future of Nature. Island Press, Covelo, CA, pp. 135-156.

Norgaard, R.B., 2002. Optimists, pessimists, and science. BioScience 52 (3), 287-292.

Nowotny, H., Scott, P., Gibbons, M., 2001. Rethinking Science: Knowledge and the Public in an Age of Uncertainty. Polity, Cambridge.

NRC, 1999a. Global Environmental Change: Research Pathways for the Next Decade. National Academy Press, Washington, DC.

NRC, 1999b. Our Common Journey. National Academy Press, Washington, DC.

NRC, 2000. Reconciling Observations of Global Temperature Change. National Academy Press, Washington, DC.

NRC, 2001. Climate Change Science, An Analysis of Some Key Questions. National Academy Press, Washington, DC.

NRC, 2003. Understanding Climate Change Feedbacks. National Academy Press, Washington, DC.

Nuclear Waste Technical Review Board, 2000. Spring 2000 board meeting transcript. Nuclear Waste Technical Review Board, Arlington, VA, http://www.nwtrb.gov/meetings/meetings.html.

Nuclear Waste Technical Review Board, 2003. An evaluation of key elements in the US Department of Energy's Proposed System for Isolating and Containing Radioactive Waste. Nuclear Waste Technical Review Board, Arlington, VA, http://www.nwtrb.gov/ reports/reports.html.

Oreskes, N., 2004. Science and public policy: what's proof got to do with it? Environ. Sci. Policy 7 (5), 369-383.

Parrot Lab, 2003. Parrot Lab, http://www.cropsoil.uga.edu/ parrottlab/.

Pielke Jr., R.A., Rubiera, J., Landsea, C., Fernandez, M.R., Klein, R., 2003. Hurricane vulnerability in Latin America and the Caribbean: normalized damage and loss potential. Nat. Hazards Rev. 4 (3), 101114.

Pielke Jr., R.A., Sarewitz, D., 2003. Wanted: scientific leadership on climate. Issues Sci. Technol. Winter, 27-30.

Pimentel, D., 2002. Exposition on skepticism. BioScience 52 (3), 295298.

Quist, D., Chapela, I.N., 2001. Transgenic DNA introgressed into traditional maize landraces in Oaxaca, Mexico. Nature 414, 541-543.
Rayner, S., 2000. Prediction and other approaches to climate change policy In: Sarewitz, D., Pielke Jr., R.A., Byerly Jr., R. (Eds.), Prediction: Science, Decision Making, and the Future of Nature. Island Press, Covelo, CA, pp. 269-296.

Rayner, S., 2003. Democracy in the age of assessment: reflections on the roles of expertise and democracy in public-sector decision making. Sci. Public Policy 30 (3), 163-170.

Rayner, S., Malone, E., 1998. Ten suggestions for policymakers. In: Rayner, S., Malone, E. (Eds.), Human Choice and Climate Change, vol. 4: What Have We Learned. Battelle Press, Columbus, OH, pp. 109-138.

Roeloffs, E.A., Langbein, J., 1994. The earthquake prediction experiment at Parkfield, California. Rev. Geophys. 32 (3), 315-336.

Rosenberg, A., 1994. Instrumental Biology or the Disunity of Science. University of Chicago Press, Chicago.

Rotmans, J., De Vries, B., 1997. Perspectives on Global Change. Cambridge University Press, Cambridge, UK.

Rowlands, I.H., 1993. The fourth meeting of the parties to the Montreal protocol: report and reflection. Environment 35 (6), 25-34, http://www.ciesin.org/docs/003-077/003-077.html.

Sandel, M.J., 1996. Democracy's Discontent: America in Search of a Public Philosophy. Harvard University Press, Cambridge, MA

Sarewitz, D., 1996. Frontiers of Illusion: Science, Technology, and the Politics of Progress. Temple University Press, Philadelphia.

Sarewitz, D., 2000. Science and environmental policy: an excess of objectivity. In: Frodeman, R. (Ed.), Earth Matters: The Earth Sciences, Philosophy, and the Claims of Community. Prentice-Hall, Upper Saddle River, NJ, pp. 79-98.

Sarewitz, D., Pielke Jr., R.A., 2000. Breaking the global warming gridlock. Atlantic Monthly July, 54-64.

Schneider, S., 2002. Global warming: neglecting the complexities. Sci Am. January, 62-65.

Schön, D.A., Rein, M., 1994. Frame Reflection: Toward the Resolution of Intractable Policy Controversies. Basic Books, New York.

Schwarz, M., Thompson, M., 1990. Divided We Stand: Redefining Politics, Technology and Social Choice. University of Pennsylvania Press, Philadelphia.

Shackley, S., Wynne, B., 1996. Representing Uncertainty in Global Climate Change Science and Policy: Boundary-Ordering Devices and Authority. Sci. Technol. Hum. Values 21 (3), 275-302.

Simon, H.A., 1983. Reason in Human Affairs. Stanford University Press, Stanford, CA.

Simon, H.A., 1997. Administrative Behavior, fourth ed. Free Press, New York.

Snow, A., 2003. Research interests. The Department of Evolution, Ecology, and Organismal Biology, The Ohio State University, http://www.biosci.ohio-state.edu/ eeob/resints/res_snow.html.

Stiglitz, J.E., 2003. Globalization and its Discontents. Norton, New York. Supreme Court of the United States, 2000. 531 US 98.

US General Accounting Office, 2001. Elections: statistical analysis of factors that affected uncounted votes in the 2000 Presidential election. GAO-02-122, 15 October, http://www.gao/gov/cgi-bin/getrpt?gao-02122.

United States House of Representatives, 2003. Politics and Science in the Bush Administration, Committee on Government Reform-Minority Staff. Washington, DC, http://www.house.gov/reform/min/politicsandscience/.

UK Climate Impacts Programme, 2001. Socio-economic scenarios for climate change impact assessment: a guide to their use in the UK. UK Climate Impacts Programme, Oxford, UK, http://www.ukcip.org.uk/ research_tools/research_tools.html.

van Asselt, M.B.A., Rotmans, J., 1996. Uncertainty in perspective. Global Environ. Change 6 (2), 121-157.

van der Sluijs, J., van Eijndhoven, J., Shackley, S., Wynne, B., 1998. Anchoring devices in science for policy: the case of consensus around climate sensitivity. Social Stud. Sci. 28 (2), 291-323. 
Wand, J., Shotts, K., Sekhon, J., Mebane Jr., W., Herron, M., Brady, H., 2001. The butterfly did it: aberrant vote for Buchanan in Palm Beach County, Florida. Am. Political Sci. Rev. 95 (4), 793-810.

Wilson, E.O., 1998. Consilience: The Unity of Knowledge. Alfred A. Knopf, New York.

Wolfenbarger, L.L., Phifer, P.R., 2000. The ecological risks and benefits of genetically engineered plants. Science 290, 2088-2093.

World Trade Organization, 1995. Agreement on the application of sanitary and phytosanitary measures. Article 2.2.

Wynne, B., 1989. Sheepfarming after chernobyl: a case study in communicating scientific information. Environment 31 (2), 11-15, 33-39.
Wynne, B., 1991. Knowledges in context. Sci. Technol. Hum. Values 16 (1), 111-121.

Daniel Sarewitz is Professor of Science and Society and Director of the Consortium for Science, Policy, and Outcomes (CSPO) at Arizona State University. Recent publications include Living with the Genie: Essays on Technology and the Quest for Human Mastery (co-edited with Alan Lightman and Christina Desser, Island Press, 2003); Prediction: Science, Decision making, and the Future of Nature (co-edited with Roger Pielke Jr. and Radford Byerly Jr, Island Press, 2000), and Frontiers of Illusion: Science, Technology, and the Politics of Progress (Temple University Press, 1996). 